\title{
AGRIBUSINESS DEVELOPMENT FOR FARMING RICE ON PROGRAM CONCERN TO FARMER FOOD SECURITY AT BOALEMO REGENCY
}

\author{
Eni Masruroh $\left.{ }^{*} 1\right)$ \\ 1) Agriculture Department, Boalemo Regency, Gorontalo, Indonesia \\ Corresponding Author E-mail: enimasruroh88@gmail.com
}

\begin{abstract}
The research aims to develop an alternative recommendation agribusiness program development paddy rice farming relation to food security in the district was. This research is quantitative. Sources of data in this research is secondary data and primary data from questionnaires. The data analysis technique used is the SWOT analysis. These results indicate that Based on the SWOT analysis proves that the strategy of the development of barns through agribusiness development program to support rice farming rice fields of food security in the district was located in quadrant I, which means it supports aggressive strategy or strategies SO. In quadrant I (aggressive) all the potential power that the majority of the district was a farmer who has the experience and motivation of farming is high, the potential for a large area, the production ability is above average, and institutional barns that support, can utilize / seize opportunities demand for rice increases, as well as increased yield harvest with agricultural intensification, so the chances of barns society has the potential to be developed further.
\end{abstract}

Keywords: Agribusiness Program; Food Security; SWOT Analysis.

\section{INTRODUCTION}

Food is a basic need for humans. Said food needs fundamental needs because if not met, then the person's life can be said to be not feasible. The fulfillment of the food is very important because it determines the quality of human resources. Compliance with food is closely related to their food supply at both the household and the community in the form of outstanding regional food reserves and government food reserves.

Food stocks held by private / traders, generally serves to anticipate a surge in demand, and to anticipate the delay in the supply of food. Meanwhile, food stocks held by households, whether individual or collective, serves to anticipation of food shortages in the dry season, and to anticipate the threat of crop failure due to natural disasters such as pests and diseases, climate anomalies and floods (Food Security Council, 2006).

Agribusiness development program paddy rice farming is one of the institutional programs in the community that has long played a role in the procurement of food, especially in the lean season. Currently agribusiness development program paddy rice field role not only in food procurement alone, more than the agribusiness development program farming of paddy should be engaged in agribusiness that can provide added value for agricultural products so that the program is not only effective in serving the food needs of its members in times of crisis but also cater to the needs of the means of production such as fertilizers, pesticides and the financial needs of its members of the 
results of the management of paddy rice farming development program based agribusiness.

Gorontalo Province is one of the provinces in Indonesia who get agribusiness development program of paddy farming for the farmers of the Ministry of Agriculture Food Security Agency through the Department of Food Gorontalo province since 2009. Where the program allocation is divided in six district / municipality. The district was one of the district entrusted with managing agribusiness development program of paddy farming for the farmers. Currently agribusiness development program of paddy farming community has been spread evenly throughout the District in Boalemo regency.

Development of agribusiness farming paddy rice for the farmers carried out for 3 (three) years through a program of land extensification and intensification of land, increase production, maintain price stability and increased capacity of farmers' skills in the face of the growing season can be adapted to the climate, as well as the institutional capacity of farmers, With this process, the public is expected to be able to manage and develop the volume of food reserve stocks to meet the needs of all members and the surrounding community in the face of scarcity of food and / or face food insecurity, contributing to an increase in income and household food security of farmers.

The problem is that agribusiness development program farming paddy implemented has not run optimally due to several factors, among others, have not been good institutional management to access information and run the program, the limited land area, level of education, skills and use of technology by farmers on rice farming fields, farmers have limited access to capital that results in low production of rice (Kunuti et al, 2020; Sulistyorini and Sunaryanto, 2020), and affect the stability of food supply and food security paddy rice farmers in the district was.

Food security is not an issue in itself but rather the production of investment management issues in the field of non-food and non-agriculture as part of the achievement of food security (Lassa, 2010). according to the Food Security Council (2006) the availability of food can be met from three sources: (1) the ability of domestic production; (2) food imports; and (3) management of food reserves.

According to Daft (2010) SWOT analysis (SWOT analysis) which includes measures to identify the strengths, weaknesses, opportunities, and threats that determine the performance of the company. Furthermore Rangkuti (2008) explains that the SWOT analysis is to identify the various factors systematically to formulate the corporate strategy. This analysis is based on the logic that maximizes strength (strength) and opportunities (opportunity), but simultaneously to minimize the weakness (weakness) and threats (threats). The decision making process is always associated with the development strategy of the mission, goals, strategies and policies of the company. Thus, the strategic planning should analyze the factors of strategy of the company (strengths, weaknesses, opportunities and threats) in the current conditions. SWOT is a strategic planning method used to evaluate the strengths, weaknesses, opportunities, and threats in in developing and strengthening business competitive strategies. (Kusbandono, 2019; Muhammad, 2018; Hernawan et al., 2019).

According to Fahmi (2013) to analyze more deeply about the SWOT, it is necessary to external and internal factors seen as an important part of a SWOT analysis, namely: External factors External factors affecting the formation of opportunities and threats $(\mathrm{O}$ and $\mathrm{T})$. Where these factors are concerned with the conditions that occur outside the company that affect the decision making of the company. These factors include the industry environment and the macro business environment, economic, political, legal, technological, demographic, social and cultural. Internal factors Internal factors affecting the formation of strengths and weaknesses (S and $\mathrm{W})$. Where these factors are concerned with the conditions that occur in the 
company, which was also influence the formation of the decision-making analysis (decision making) companies. Internal factors include all kinds of functional management: marketing, finance, operations, human resources, research and development, information management systems and corporate culture (corporate culture).

SWOT analysis of internal and external conditions of an organization which will then be used as the basis for designing the strategy and work program. Internal analysis includes assessment of the factor of Strength and Weakness. Meanwhile, external analysis includes factors Opportunity and Threat. This process involves determining the specific purpose of speculation or effort and identifying the internal and external factors that support and that is not in achieving that goal. SWOT analysis can be applied by means of analyzing and sorting out the various things that affect the fourth factor, then apply the SWOT matrix image, where the application is (a) how power is able to take advantage of existing opportunities; (b) how to overcome the weaknesses to take advantage of existing opportunities; (c) how the strength to face the existing threats; (d) how to overcome the weaknesses that can prevent the threat becomes real, or the emergence of a new threat. With mutual disjunction of four factors, then makes this analysis provides an easy to realize the target of a business.

The purpose of this study is to arrange an alternative recommendation agribusiness program development paddy rice farming relation to food security in the district was.

\section{METHOD}

This study was conducted in the district was in January to March 2020. The method used is survey method. With a total sample of 101 farmers spread across two districts. The analytical tool used in this study are: To determine the development strategy of paddy farming agribusiness program in support of food security is done by using SWOT analysis to identify factors that are strengths, weaknesses, opportunities and challenges (internal barns) and the factor of government policies and programs (external barns).

a. Calculating a score (a) and weight (b) point factor and total number multiplication factor scores and weights $(c=a \times b)$ on each SWOT factor; Calculate a score (a) each point factors conducted independent (assessment of a point factor should not be influenced or influence the assessment of the point of other factors. Options range scale score will determine the accuracy of ratings, but is commonly used is from 1 to 10 , with assuming a value of 1 means the lowest score and 10 is what's most high score.

b. Reducing the total number of factors $S$ to $W(d)$ and factor $O$ with $T(e)$; Scoring (d $=x)$ further into the value or point on the $X$ axis, while the scoring $(e=y)$ further into the value or point on the $Y$ axis;

c. Looking organizational position indicated by the point $(x, y)$ on the SWOT quadrant.

\section{RESULTS AND DISCUSSION}

Agribusiness Program Development Strategy Rice Relation to Food Security in the District was

To find out more about the development strategy barns to support the food security of farmers of paddy in the district was, is to identify ways of alternative, so it can use the power in particular to take chances, minimize weaknesses, and use force to overcome the threat and minimize your weaknesses by avoiding threats, This can be seen in the following Table 1. 


\section{SO strategy}

With the majority of farmers who have the experience and motivation of farming high, the potential for a large area, the production ability is above average, and institutional barns that support, we can exploit / seize opportunity rice demand that increased, as well as increased yields with agricultural intensification, so the chances of barns society has the potential to be developed further.

\section{WO strategy}

The weakness at the farmers, with the conditions of supply of seeds and fertilizers are often late, small land and a lack of support for capital support makes it difficult to seize the opportunities that exist. We should remove caused opportunities for. Strategy limitation factor that must be done is the farmers should produce at a fixed scale or normal, that aim is to keeping the supply of rice, although not to meet increasing market needs.

\section{ST strategy}

The availability of rice stocks for members of barns and rice production that is above the national average standard can be overcome when a farmer when shortages of rice caused by crop failure due to pests, climate change or natural disasters. The challenges of globalization of trade and industry which are a threat can be converted into an opportunity that can be achieved with the production capability of standard rice above the national average and the availability of stocks stable.

\section{WT strategy}

To be able to anticipate any loss or minimize potential losses harvest, natural disaster, or falling prices during the harvest, the farmer should perform the control or restrictions on rice production scale. In circumstances where the availability of seeds and fertilizers are often too late and the difficulty farmers' access to capital institutions should farmers produce in normal scale or fixed or reduce the scale of production and should not force to increase the scale of production. If it still carried the potential for capital loss incurred will be larger farmers will not be able to be covered by the market price.

SWOT Analysis is a strategic planning method used to evaluate the strengths, weaknesses opportunities and threats involved in a particular condition, project or business. This involves specifying the objective and identify the internal factors and external favorable and unfavorable to achieving a goal. SWOT analysis comparing internal and external factors (Rangkuti, 2004). 
Table 1. SWOT Matrix

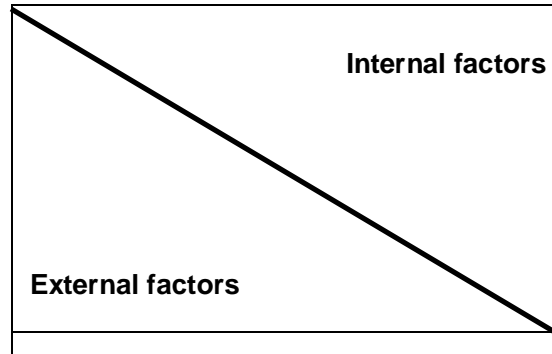

Opportunities (0):

The availability of facilities and infrastructure (input demand alsintan) enough support

b. Demand tends to increase so that rice barns agri-based society has pretty good chances to be developed

c. The development of science and technology both rice cultivation and marketing of the crop

d. Yields can be increased with the intensification of agriculture

e. Industry / SMEs processing agricultural produce much use rice

\section{Threats (T):}

a. Globalization of trade and industry

b. Climate change/ season uncertain

c. Natural disasters

Pests and plant diseases that result in decreased productio

e. Rice prices tend to fall when the harvest.

\section{trength (S):}

a. The majority of the population are farmers

b. Farming experience and high motivation

c. Potential agricultural land, especially paddy fields large enough

d. Rice production above the average standard national rice production

e. Institutional barns community are expected

Institutional barns strongly support the farming community of paddy

\section{Strategy (SO):}

With the experience and motivation of farming High, the potential for a large area, the production ability is above average, and institutional barns that support, we can exploit / seize opportunity of rice demand that increased, as well as increased yields with agricultural intensification, so the chances of barn community food has the potential to be developed further.

With the majority of the population as a farmer with a high level of With the majority of the population as a farmer with a high level of faming experience, will bepulad enough to increase the production capacity of farmers. The increase in production capacity means also affect production output quantities.

Market demand for rice increases, only to do with the ability of rice stocks that match or exceed the requirements. In that sense, the potential of farmers' land and the availability of food supplies into the main capital.

\section{Strategy (ST):}

The availability of rice stocks for members of barns and rice production that is above the national average standard can be overcome when a farmer when shortages of rice caused by crop failure due to pests, climate change or natural disasters.

The challenges of globalization of trade and industry which are a threat can be converted into an opportunity that can be achieved with the production capability of standard rice above the national average and a stable stock availability.

\section{Weakness (W)}

a. Availability of seeds of paddy and fertilizer are often late

b. The education level of farmers is still low

c. Small-scale land ownership and traditional

d. Institutional barns are not strong

e. Difficult to access finance institutions

\section{Strategy (WO):}

The weakness at the farmers, with the conditions of supply of seeds and fertilizers are often late, small land and a lack of support for capital support makes it difficult to seize the opportunities that exist. We should remove the opportunities because of factor limitations.

Strategies that should be done is the farmers should produce at a fixed scale or normal, that aim is to keeping the supply of rice, although not to fulfill increasing market needs.

\section{Strategy (WT):}

To be able to anticipate any loss or minimize potential harvest loss, natural disaster, or falling prices during the harvest, the farmer should perform the control or restrictions on rice production scale.

In circumstances where the availability of seeds and fertilizers are often too late and the difficulty farmers' access to capital institutions should farmers produce in normal scale or fixed or reduce the scale of production and should not impose to increase the scale of production. If it still carried the potential for capital loss incurred will be larger farmers will not be able to be covered by the market price. 
Table 2. Internal Analysis of Food Barn Internal Development Strategy

\begin{tabular}{|c|c|c|c|c|}
\hline \multirow[t]{2}{*}{ No. } & \multirow{2}{*}{$\begin{array}{c}\text { Internal factors } \\
\text { Strength } \\
\end{array}$} & \multicolumn{3}{|c|}{ Score Weight } \\
\hline & & Weight & Rating & Score Weight \\
\hline 1. & $\begin{array}{l}\text { The majority of the population are } \\
\text { farmers }\end{array}$ & 0.09 & 4 & 0.33 \\
\hline 2. & Experience and motivation high farming & 0.09 & 4 & 0.34 \\
\hline 3. & $\begin{array}{l}\text { Potential agricultural land, especially } \\
\text { paddy fields large enough }\end{array}$ & 0.08 & 4 & 0.27 \\
\hline 4. & $\begin{array}{l}\text { Rice production above the average } \\
\text { standard national rice production }\end{array}$ & 0.08 & 2 & 0.20 \\
\hline 5. & $\begin{array}{l}\text { Institutional barns community are } \\
\text { expected }\end{array}$ & 0.09 & 4 & 0.32 \\
\hline 6. & $\begin{array}{l}\text { Institutional barns strongly support the } \\
\text { farming community of paddy }\end{array}$ & 0.08 & 3 & 0.28 \\
\hline 7. & $\begin{array}{l}\text { Rice available food reserves for } \\
\text { members in barns }\end{array}$ & 0.09 & 4 & 0.31 \\
\hline \multirow[t]{3}{*}{8.} & $\begin{array}{l}\text { Farm capital available to members in } \\
\text { barns }\end{array}$ & 0.08 & 4 & 0.31 \\
\hline & & & & 2.35 \\
\hline & \multicolumn{4}{|l|}{$\begin{array}{c}\text { Weakness } \\
\end{array}$} \\
\hline 1. & $\begin{array}{l}\text { Availability of seeds of paddy and } \\
\text { fertilizer are often late }\end{array}$ & 0.07 & 3 & 0.17 \\
\hline 2. & $\begin{array}{l}\text { The education level of farmers is still } \\
\text { low }\end{array}$ & 0.06 & 2 & 0.13 \\
\hline 3. & $\begin{array}{l}\text { Small-scale land ownership and } \\
\text { traditional }\end{array}$ & 0.07 & 2 & 0.16 \\
\hline 4. & Institutional barns are not strong & 0.08 & 3 & 0.22 \\
\hline \multirow[t]{3}{*}{5.} & Difficult to access finance institutions & 0.07 & 2 & 0.15 \\
\hline & & & & 0.83 \\
\hline & Total & & & 1.53 \\
\hline
\end{tabular}

Source: Data processed, 2020

Based on the Table 2, it can be seen that the total value of strength is 2.35 , this value is obtained based on the amount of weight multiplied by the rating then the result values summed to produce the total value. The same method was also carried out to obtain the value of weakness. The total value obtained from weakness amounted to 0.83. This shows that the strength of the factors in the development of barns in the Boalemo regency by a factor greater than weaknesses. As for the main force is the value of the forces that have reduced the value of the weaknesses and the result shows 2.35 to $0.83=1.53$.

Table 3. External Analysis of Food Barn Internal Development Strategy

\begin{tabular}{|c|c|c|c|c|}
\hline No. & Eksternal factors & \multicolumn{3}{|c|}{ Score Weight } \\
\hline & Opportunity & Weight & Rating & Score Weight \\
\hline 1. & $\begin{array}{l}\text { The availability of facilities and } \\
\text { infrastructure (input demand, alsintan) } \\
\text { enough support }\end{array}$ & 0.10 & 3 & 0.26 \\
\hline 2. & $\begin{array}{l}\text { Demand tends to increase so that rice } \\
\text { barns agri-based society has pretty } \\
\text { good chances to be developed }\end{array}$ & 0.11 & 3 & 0.31 \\
\hline 3. & $\begin{array}{l}\text { The development of science and } \\
\text { technology both rice cultivation and } \\
\text { marketing of the crop }\end{array}$ & 0.11 & 3 & 0.32 \\
\hline 4. & $\begin{array}{l}\text { Rice yields can be increased with the } \\
\text { intensification of agriculture }\end{array}$ & 0.11 & 3 & 0.32 \\
\hline 5. & $\begin{array}{l}\text { Industry / SMEs processing agricultural } \\
\text { products many of which use rice }\end{array}$ & 0.09 & 2 & 0.22 \\
\hline
\end{tabular}




\begin{tabular}{|c|c|c|c|c|}
\hline \multicolumn{5}{|c|}{$\begin{array}{r}\text { Threat } \\
\end{array}$} \\
\hline 1. & Globalization of trade and industry & 0.09 & 2 & 0.21 \\
\hline 2. & Climate change / season uncertain & 0.10 & 3 & 0.27 \\
\hline 3. & Natural disasters & 0.10 & 3 & 0.29 \\
\hline 4. & $\begin{array}{l}\text { Pests and diseases in rice crops } \\
\text { resulting in a decrease in rice } \\
\text { production }\end{array}$ & 0.10 & 3 & 0.31 \\
\hline \multirow[t]{3}{*}{5.} & $\begin{array}{l}\text { Rice prices tend to fall when the } \\
\text { harvest }\end{array}$ & 0.10 & 3 & 0.25 \\
\hline & & & & 1.34 \\
\hline & & & & 0.09 \\
\hline
\end{tabular}

Source: Data processed, 2020

Based on the Table 3, it can be seen that the total value of the opportunity is $1: 42$, this value is obtained based on the amount of weight multiplied by the rating then the result values summed to produce the total value. The same method was also carried out to obtain the value of the threat. The total value obtained from threats by 1.34. This shows that the opportunities of the factors in the development of barns in the Boalemo regency greater than the threat factors that could have happened. As for the main chance is the probability of the reduced value of the threat and the results showed 1.42 to $1.34=0.09$.

\section{Opportunities}

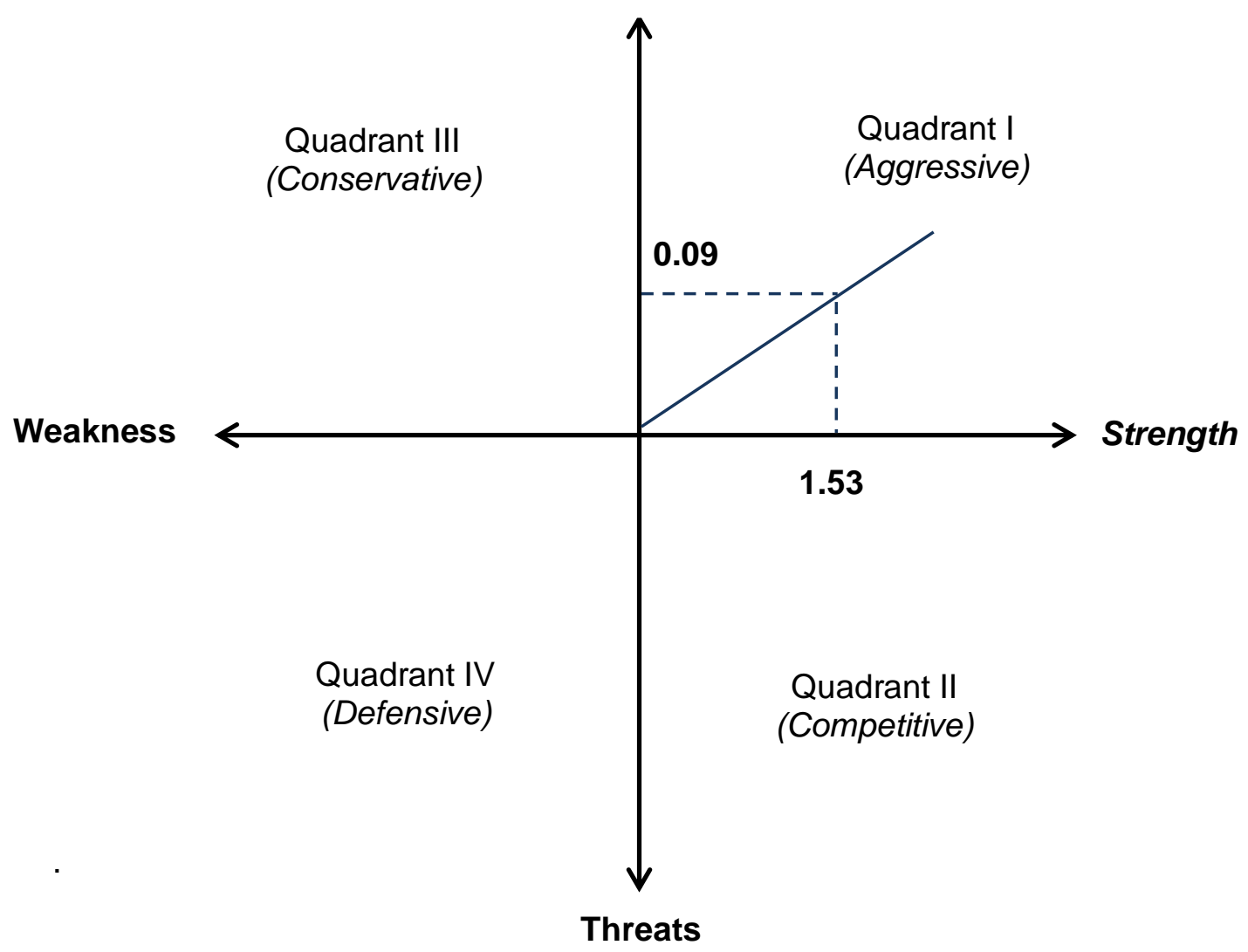

Figure 1. Diagram of SWOT Analysis 
Based on the Figure 1, it can be concluded that the strategy of the development of barns to support food security paddy rice farmers in the district was located in quadrant I, which means it supports aggressive strategy or strategies S-O. In Quadrant I (aggressive) all the potential power that the majority of the population Boalemo Regency are farmers who have the experience and high motivation of farming, the potential for a large area, the production ability is above average, and institutional barns that support, can utilize/seize opportunity rice demand that increased, as well as increased yield harvest with agricultural intensification, so the chances of barns community is very potential to further developed. The majority of the population as a farmer with a high level of farming experience, will be good enough to increase the production capacity of farmers. The increase in production capacity means also affect production output quantities. Market demand for rice increases, only to do with the ability of rice stocks that match or exceed the needs of

\section{CONCLUSION}

Based on the SWOT analysis proves that the strategy of the development of barns through agribusiness development program to support rice farming rice fields of food security in the district was located in quadrant I, which means it supports aggressive strategy or strategies S-O. In quadrant I (aggressive) all the potential power that the majority of the district was a farmer who has the experience and motivation of farming is high, the potential for a large area, the production ability is above average, and institutional barns that support, can utilize/seize opportunities demand for rice increases, as well as increased yield harvest with agricultural intensification, so the chances of barns society has the potential to be developed further.

Training programs for institutional management skills for farmers need to be implemented to compensate for the farmer education capacity is still low (average of primary and junior education) so that the development of paddy rice farming agribusiness programs related to food security paddy rice farmers will be increased in the district was.

Barns alternative development strategy is more focused on institutional strengthening barns that food availability and food access remains stable and can meet the needs of the market.

\section{REFERENCES}

Daft, Richard L. 2010. New Era Management, Edward Tanujaya. 9. Issue Salemba Four

Food Security Council. 2006. General Food Security Policy 2006-2009. Jakarta.

Hernawan, Y., Musafa, \& Dewi, S. W. K. 2019. Development Of Business Strategies Using Swot Analysis In Palasari Coffee Bandung. Jurnal IImiah Manajemen Emor (Ekonomi Manajemen Orientasi Riset), Vol. 3(1), 14-28.

Kunuti, S. A., Rauf, A., \& Saleh, Y. (2020). Perbandingan Hasil Panen Usahatani Padi Sawah Menggunakan Combine Harvester Dan Sistem Bawon Di Kabupaten Gorontalo. Jambura Agribusiness Journal, 1(2), 63-70.

Kusbandono, D. 2019. Analisis SWOT Sebagai Upaya Pengembangan dan Penguatan Strategi Bisnis (Studi Kasus Pada UD. Gudang Budi, Kec. Lamongan). JPIM (Jurnal Penelitian Ilmu Manajemen), Vol. 4(2), 921-932. 
Lassa, J. 2010. Food Security Politics Indonesia 1950-2005. http://www.zef.de/module/register/media/3ddf_Politik\%20Ketahanan\%20Pangan \%20Indonesia\%201950-2005.pdf, Accessed on January 15, 2018.

Muhammad, M. 2018. Analisis SWOT Sebagai Strategi Pengembangan Usahatani Buah Naga Merah (Hylocereus Costaricensis) Kecamatan Wasile Timur Kabupaten Halmahera Timur. Agrikan: Jurnal Agribisnis Perikanan, Vol. 11(1), 28-37.

Rangkuti, Freddy. 2008. Analisa SWOT Teknik Membedah Kasus Bisnis. Jakarta: Gramedia Pustaka Utama.

Sulistyorini, S., \& Sunaryanto, L. T. (2020). Dampak Efisiensi Usahatani Padi Terhadap Peningkatan Produktvitas. Jambura Agribusiness Journal, 1(2), 43-51. 